\title{
INTÉZMÉNYI ELEMEK ÉRTÉKEI A NEMZETI VAGYONBAN
}

\author{
Török László dr. univ. \\ Debreceni Egyetem levelezős PhD hallgatỏja
}

\section{SUMMARY}

Until the recent past economists identified the assets of a nation as the sum of material assets, human and social capital. However they found, that the differences of the calculated national assets are not proportional to the welfare of the citizens of the compared countries, therefore they looked for further explanatory variables. The specialists of the World Bank according to the results of their research identified an invisible resource, which is the institutional system of the country. Present study examines ten Hungarian institutional components from the aspect of their value and examines how they are contributing to national assets, hereby how they serve the interest of social welfare.

Kulcsszavak: nemzeti vagyon, intézményi elemek, társadalmi töke, eröforrások, társadalmi jólét

\section{BEVEZETÉS}

A tanulmány azt vizsgálja, hogy Magyarországon a nemzeti vagyon különböző összetevői közül az intézményi elemek milyen szerepet töltenek be a nemzet láthatatlan vagyonában. A nemzeti vagyon fogalmának pontos meghatározása máig a közgazdaságtudomány egyik vitatott területe. A tudományág kezdeti időszakában az értékmeghatározás kizárólag a természeti és tárgyiasult (látható, mérhető, számolható) anyagi javakra vonatkozott, így például a bányászható természeti kincsekre, a megmüvelhetö földterületekre stb. $\mathrm{A}$ tudományág fejlődésének következő állomását az értékmeghatározás vonatkozásában az emberi tőke megbecslése jelentette, amikor is megkísérelték számszerüsíteni az egyén fizikai adottságainak és szellemi képességeinek értékét, és ezt részévé tették a nemzet vagyonának. Ehhez az a felismerés szolgált alapul, hogy az emberi tudásnak gazdasági értelemben értéke van. Ennek az emberi tőkeértéknek a felmérése már egy másik gazdaságelméleti területet, mégpedig - a látható anyagi javakkal ellentétben - az ún. láthatatlan javak értékmeghatározását érintett. A közelmúltig ezek együttesen adták egy nemzet vagyonát. Mivel azonban a szakemberek azt tapasztalták, hogy az egyes nemzetek vagyonának eltérései nem állnak arányban az állampolgáraik jólétével, újabb módszereket kerestek arra, hogy az ebbéli eltéréseket magyarázni tudják. Így jutottak annak felismerésére, hogy a fizikai tökeelemek, valamint az emberi és kapcsolati tőke mint láthatatlan erőforrások mellett létezik egy harmadik hasonló értékelem is, mégpedig a társadalmi tőketényezők, azok közül is mindenekelött az intézményrendszer az, amely az emberek életminőségének legrelevánsabb tényezője (World Bank 2006).

A tanulmány az utóbb említett láthatatlan magyarországi vagyonelemeket fogja leírni és elemezni abból a megközelítésböl, hogy milyen értéket képviselnek, mennyiben járulnak hozzá a nemzeti vagyonhoz, és így miként szolgálják a nemzet polgárainak jólétét. Nem célja a dolgozatnak az, hogy számszerüsítse ezt a láthatatlan, de az életminöséget döntően befolyásoló vagyontömeget, az azonban igen, hogy empirikus kutatások eredményei és a szerző saját szubjektiv értékítélete alapján valószínüsitse azt, hogy az intézményrendszer vizsgált elemei milyen szerepet töltenek be a nemzeti vagyon alakulásában. Egy ennek megválaszolására irányuló elemzés részben arra is alkalmas, hogy választ adjon a szegény és elmaradott, valamint a felzárkózó országok ilyen állapotának miértjére (Bailey 2007).

A tanulmány módszertanában megkülönbözteti a tőkeelemek két főbb csoportját. E szerint léteznek a fizikai tőkeelemek (a nem megújuló természeti eröforrások, a mezö- és erdőgazdálkodási területek, illetve az építetett és müszaki vagyonelemek) valamint a láthatatlan tőke elemei. Az elemzés szempontjából az utóbbi csoport releváns. Ennek három alcsoportja különböztethető meg. 
Emberi/humán tőke (human capital): ez a szakértelmet, a hozzáértést, egy adott tevékenység végrehajtására való képességet takarja. Innovativ és megújulásra képes, az emberek azon szellemi képességeit jelenti, melyek megfelelö akciókkal (pl. tanulással, képzéssel, tapasztalatszerzéssel) tovább bővíthetők. A humán tőke alapvetően testre szabott, és valamilyen bensỏvé válást feltételez. A felhalmozást egy elsajátítási folyamat elözi meg, amely képzési és tanulás idöt igényel, $s$ ahol az időt személyesen kell beruházni. Az emberi töke elsajátítása - koroktól, társadalmaktól és társadalmi osztályoktól függően - különbözö mértékben mehet végbe. Sokrétüen kötődik a személyhez, annak biológiai egyedülvalóságához és állapotához, tehát az egyén személyes képességeihez és egészségi helyzetéhez. A tőketípus társadalmi átörökítés útján kerül továbbadásra, ami azonban mindig rejtetten történik, és gyakran teljesen láthatatlan marad.

Kapcsolati tőke (relational capital): a gazdaság egyes szereplöi közötti interakciókat, tudástranszfert és tapasztalatcserét jelenti, nemcsak országon belül és kormányzati szinten, hanem országok, régiók és települések között is. Ez a tőkeelem ugyanakkor képesség közös célok elérése érdekében való együttműködésre, és bizalmi tőke is egyben. Nagysága azon kapcsolatok hálójának kiterjedésétől függ, ame!yeket ténylegesen mozgósítani tud az egyén. $\mathrm{Ez}$ a rendszer azoknak az egyéni vagy kollektív beruházási stratégiáknak a terméke, amelyek tudatosan vagy öntudatlanul olyan együttmüködés megteremtésére irányulnak, amelyek elöbb-utóbb közvetlenül haszonnal kecsegtetnek.

Társadalmi tỏke (social capital): az a közjószág, ami azt jelenti, hogy nem személyes tulajdona azoknak, akiknek hasznára válik, illetve általában nem magánszemélyek biztosítják. A társadalmi tőke tipikusan kötelékekből, normákból, bizalomból - ide sorolva az emberek társadalomban való bizalmát is -, intézményekből áll össze, és átvihető egyik társadalmi környezetböl a másikba. A felsoroltak serkentöleg hatnak a termelékenységre, de a szervezeti tőke tárgyát képezi többek közt a megfelelő és hatékony kormányzási és igazságszolgáltatási rendszer is (Putnam 1993).

\section{INTÉZMÉNYI TŐKE ELEMEI}

A legfontosabb intézményi elemeket tíz összetevőben határozta meg a Világbank hivatkozott tanulmánya, ezek hazai megjelenését és állapotát egyenként fogom bemutatni és értékelni.

\subsection{SZAVAZATI JOG}

Fontossági sorrend nem lévén, elsőként a szavazati jogot értékelem abból a szempontból, hogy miként járul hozzá közvetetten a társadalmi jóléthez. Tudott dolog, hogy az elismert emberi jogok minden ember jussa. Demokráciában a politikai jogok nélkülözhetetlenek a közösségi és társadalmi életben való részvételhez, ezek alapján lehet egy párthoz csatlakozni, szabadon gyülekezni, véleményt formálni, és azt kinyilvánítani, valamint információkhoz jutni, de leginkább szavazni és választani. Minden választásra jogosultnak azonos értékü szavazati joggal kell rendelkeznie, de ez nem jelenti azt, hogy mindenkinek a szavazatta egyenlő hatásfokú. Az egyenlöség elve azt jelenti, hogy minden szavazásra jogosult egyenlő jogokkal vesz részt a választásban, azonban az egyenlőség elvét a következőképpen kell értelmezni: a választójog egyenlösége nem jelenti és nem is jelentheti a választáskor kifejezett politikai akaratok csorbítatlanul egyenlő érvényesülését (Alkotmánybiróság 1991). A szavazati jog kiterjesztése nálunk megfelelő, a jogok gyakorlásának feltételei biztosítottak és azokat semmi nem veszélyezteti.

\subsection{ELSZÁMOLTATHATÓSÁG}

Az elszámoltathatóság azt jelenti, hogy a társadalmi berendezkedés valamennyi szervének és azok tagjainak indokolniuk kell döntéseiket, és azokért felelősséget kell vállalniuk más 
szervek, adott esetben pedig a bíróság előtt. Jelenti továbbá azt, hogy milyen mértékben térhetnek el az elvi felelősségüktől és következik belöle az érintettek kérdőre-vonhatósága és hibáztathatósága is. Az elszámoltathatóság fejlett jogi intézményrendszert feltételez, olyat, amely alkalmas - adott esetben - a felelösségre-vonásra. Ezzel az intézményi elemmel szemben egyre erőteljesebb kritikák fogalmazódnak meg: „Az államgépezet elvileg jelentős erőkkel rendelkezik, hogy kényszerrel biztositsa a normák követését. Csakhogy az államrendszer adott müködése miatt a felelösségre vonási igény csekély, a jogérvényesítésre szolgáló erőforrások elégtelenek. A hatóságok rendszertelenül szankcionálnak, és van, amikor szisztematikusan kivételeznek. Így a szankcionálás nem lehet hiteles. Sok szempontból véletlen eseménynek túnik, emiatt gyakran hiányzik visszatartó ereje. Elégtelen a normaszegők társadalmi elitélése. A társadalom helytelenítése nélkül, pusztán büntetéssel lehetetlen egy normarendszert fenntartani. Igaz, személyes felelősségre vonás nélkül sem lehet normarendszert múködtetni"' (Sajó 2008 704.). Véleményem szerint az ország társadalmi berendezkedése szerveivel és intézményeivel, azok tagjaival és alkalmazottaival (az esetenkénti tévedései és részrehajlásai ellenére is) alapvetően képes megfelelni az elszámoltathatóság követelményének.

\subsection{POLITIKAI STABILITÁS}

A politikai stabilitás legfontosabb ismérve az, hogy az államnak (annak mindenkori kormányának) tudni kell biztosítani a demokratikus berendezkedés fennmaradását. Több empirikus kutatás megállapította, hogy az állam legitimitása és tekintélye a magyarországi közfelfogásban kétes. Abban, hogy ez így van, alapvető szerepet jảtszik a szélsőséges politikai szembenállás, mert pártpolitikai alapállásból rendszeresen aláássák az állam tekintélyét. A magyar állami és pártrendszer nem kedvez a pártatlanságnak és professzionizmusnak, ami miatt csak korlátozott legitimációra számíthat a társadalom irányából. A tanulmány írásának időpontjában egyre mélyülő pénzügyi-gazdasági válság tapasztalható, ebböl eredően a jóléti-szociális kiadások jelentős csökkenése várható, melynek következményeként a társadalom széles rétegei életszínvonalának romlása konstatálható. Egy elhúzódó gazdasági visszaesés, az ezzel együtt járó munkanélküliség-növekedés, az egzisztenciális ellehetetlenülés fenyegetettségével nézve, valamint az egyéni, társasági és nemzetgazdasági szintü eladósodás fokozódása erősen megnöveli a populizmust, ami közvetve a politikai stabilitás meggyengülésével járhat. Ez a veszély (habár létezik) ma csak mérsékleten áll fenn, az ország demokratikus berendezkedése stabil.

\subsection{TÁRSADALOM ERŐSZAKMENTESSÉGE}

A társadalom eröszakmentessége a következö értékelendő elem. Itt azt kell megvizsgálni, hogy az egyes emberek, illetve azok csoportjai mennyiben képesek az ellentéteiket erőszakmentesen megoldani (ami egyben egy demokrácia fejlettségének a fokmérője is). Ilyen politikai-gazdasági válságos időben egyértelmüen tapasztalható a konfliktusok számának növekedése, ami magától értetődően következik a társadalmi feszültségek szaporodásából. Az egyének között megnyilvánuló erőszakos cselekmények számának drasztikus növekedését csak lassan követi a csoportosan elkövetettek emelkedése, de ami némileg kedvező ebben a tendenciában, hogy azok nem politikai indíttatásúak. Különbözö társadalmi csoportok közötti erőszakos összecsapásokra eddig nem került sor, ellenben a feszültség növekedése tapasztalható. Ennek alapvető okai a társadalmi és jövedelmi egyenlőtlenségek növekedése, a szegregáció, a nem kezelt társadalmi feszültségek, a csoportok ellentétes értékei. Ezen okok nem vagy csak felületes kezelése szélesedő társadalmi elégedetlenséget válthat ki. Ennek mérséklésében az lenne releváns, hogy a társadalmak (köztük a mai magyar társadalom is) folytonos gazdasági növekedése a többség számára jólétet és biztonságot nyújtson, továbbá a mindenkori hatalom a javạk demokratikus elosztásával csökkentse az egyenlőtlenséget, ezzel 
járulva hozzá a társadalom tagjainak magasabb szintű szubjektív életminőségéhez (Utasi 2009). Megitélésem szerint azért, mert összességében az erőszakmentesség csökkenése tapasztalható mind az egyéni, mind pedig a társadalmi kapcsolatokban, az ellentétek megoldásának egyre nagyobb hányadában kerül sor atrocitásra, ezért ez az intézményi elem összességében inkább negatív szerepet képvisel.

\section{5. ÁlLAMIGAZGATÁS HATÉKONYSÁGA}

Ötödikként az államigazgatási tevékenység hatékonyságát szükséges értékelni, amikor is az vizsgálandó, hogy a meglévő erőforrásokat (tárgyiakat és emberieket) mennyire ésszerüen használják fel a közszolgáltatások nyújtásában. Ebben a vonatkozásban az államigazgatás tulajdonképpen nem más, mint amikor annak szervezetei a közhatalom eszközeivel érvényesítik az általuk annak minősített közérdeket. A hazai állami szabályozás és a jogrendszer kirívóan magas költségekkel müködik, melynek egyik determináló tényezője az, hogy ezekkel az intézményekkel szemben alacsony fokú a társadalmi bizalom. Eredményességük emelkedésének alapvető bázisa az lenne, ha ezt a bizalmi fokot sikerülne lényegesen növelni. Az alacsony hatékonyság másik tényezöje az, hogy az állami szabályozó és szolgáltató szervezetek bevételeikböl tartják fenn müködésüket, emiatt érdekeltek a hosszas eljárásokban és a magas költségekben. A harmadik magyarázó tényezỏ a hatékonytalanságban, az állami szabályozás költségeinek folyamatos emelkedésében a szabályozás hatókörének bővítésére irányuló permanens törekvés. „Az etikai normák folyamatosan lazulnak, a kormányzat pedig a szabályozási illúzió rabja. Ez annyit jelent, hogy a szabályozás alóli kibúvónak rendszeressé válására mindig a szabályozás további szigorítása, azaz bonyolítása a válasz, így pedig az etikai normák még tovább gyengülnek." (Török 2007 1073.). Általánosan elfogadott tény, hogy a hazai államigazgatás mérete túlságosan nagy, hatékonysága pedig kicsi. Ez odáig vezet, hogy müködése drága, vagyis fenntartása aránytalanul sok erőforrást von el a társadalom egyéb területeitől. Véleményem szerint tehát ez az intézményi elem összességében - nem a léte, hanem a túlterjedtsége okán - negatív szerepet tölt be a láthatatlan nemzeti vagyonban, ezért nem a tőle elvárható mértéken szolgálja a nemzeti jólétet.

\subsection{SZABÁLYOZẢS MINŐSÉGE}

A modern polgári demokráciákban az állampolgárok azt várják el kormányaiktól, hogy azok gondoskodjanak biztonságukról, segítsék elö jólétük megvalósítását. A vállalkozások és egyéb szervezetek pedig azt, hogy egyenlő feltételekkel biztosítsák számukra a hazai és nemzetközi versenyképességet. Az állam tevékenysége nem egyszerüen szervezési-technikai jellegü feladatmegoldás, hanem egyúttal a közjó szolgálata érdekében tett erőfeszítés (Báger et. al. 2010). Az államigazgatás ezeknek a közérdekeknek a megvalósulása érdekében szabályokat dolgoz ki. Ezek megalkotása során törekedni kell a legmagasabb fokú hatékonyságra. Ez azt jelenti, hogy a jogszabályalkotóknak biztosnak kell lenniük abban, hogy a legmegfelelöbb eszközöket veszik igénybe a feladat végrehajtására, miközben a társadalom szempontjából a negativ hatásokat a legkisebbre csökkentik, az előnyöket pedig a lehetö legjobban kihasználják, s teszik mindezt a tárgyban érintett valamennyi fél meghallgatásával. A szabályok betartása adja a szabályozás minőségi garanciáit. A szabályozás minöségének mérésére kidolgozott indikátor aggregálja a kormányzat azon képességére vonatkozó mutatókat, melyek az előzőekben megfogalmazott célok elérését elösegítő politikák és szabályok megtervezéséhez és megvalósításához szükségesek. Álláspontom szerint a szabályalkotás negatív hatásai erősödő tendenciát mutatnak. Ez leginkább a gyakori változtatásokban érhető tetten, ami különösen kirívó a gazdasági szabályozás területén. Máskor pedig úgy tünik, hogy a jogalkotás lemarad a társadalom életében bekövetkezett változásoktól. Sok esetben túlszabályozás tapasztalható. Mindezek 
ellenére a hazai jogszabályalkotás - igazodva az uniós normákhoz és iránymutatásokhoz megfelel a kor követelményeinek. Összességében azt állítom, hogy a szabályozás minősége megfelelö módon járul hozzá a láthatatlan nemzeti vagyonhoz.

\subsection{TÖRVÉNYESSÉ ÉS JOGBIZTONSÁG ÉRVÉNYESÜLÉSE}

A törvényesség érvényesülésének megítélése a következő, mely terület kapcsolódik az elözö tételhez. Ennek követelménye kimondja, hogy a törvények akkor jók, ha azokban összhangban vannak az egyéni és közérdekek, valamint a benne foglaltak betarthatók. Az érdekek felismerése és azok összehangolása feltételezi a társadalom alapos ismeretét, a benne zajló folyamatok megértését. A sok esetben eltérő érdekek összehangolása kifinomult valóságérzéket feltételez és objektíve nem is mindig kivitelezhetö. A betarthatóság feltételei az esetek döntő többségében biztosítottak, az államigazgatásnak megfelelö intézményi eszközök állnak rendelkezésre ahhoz, hogy kikényszerítsék a törvények betartását, megsértésük esetén pedig érvényesítsék a szankciókat. A jogbiztonság a jogállam meghatározó eleme, minden állam jogrendjének elérendő célja. A jogbiztonság önmaga is több elemből, alapkövetelményből tevődik össze, amelyek közül a legfontosabbak: a jog hozzáférhetősége, megismerhetősége, a jog egyértelműsége és érthetősége, a jog bizonyossága és feltétlen megvalósulása. A jogbiztonság érvényesüléséhez szükséges a jogalkotás alkotmányos rendjének megtartása, a jogalkotás során a jogforrási hierarchia követelményeinek figyelembe vétele, a végrehajtó és bírói hatalom müködésének törvényhez kötése, illetve fontos elemként jelentkezik még a visszaható hatályú jogalkotás tilalma, amely a kötelezettségek és egyes magatartások jogellenessé nyilvánításának korlátját jelentik. A bírósági reformmal szemben az Európai Uniótól kapott figyelemfelhívások ellenére ennek a vagyonelemnek az értékelése összességében az, hogy megfelel a demokratikus társadalom elvárásainak.

\subsection{A KORRUPCIÓ ÁLLAPOTA}

Nyolcadik elemként a korrupció hazai állapotát kell megítélni. Korrupcióról akkor beszélünk, amikor egyéni haszonszerzésböl visszaélnek a közhatalommal. Ilyenkor az állami, társadalmi szervezetek vezetői, alkalmazottai megvesztegethetőségét lehet feltételezni. Ennek a társadalmi jelenségnek az elemzésekor nem lehet eltekinteni attól, hogy azt mikor végezzük. (Bár a korrupció mindig jelenlévő társadalmi probléma.) Úgy tartják ugyanis, hogy válságos időszakokban - mint amilyet most is élünk - a jelenség ellen küzdő intézmények müködésének hatékonysága gyengül, leginkább a szükülö erőforrásaik miatt. A korrupciót egyre inkább szervezett formában és kevésbé alkalmi jelleggel követik el. „A társadalmi élet meghatározó területein meg-megújuló küzdelem zajlik az állami erőforrások újraelosztásáért. $\mathrm{Az}$ újraelosztás a mindenkori elosztási részesedés elosztására vonatkozik, mivel a jövedelemszerzésnek nem a termelő tulajdon hatékony felhasználása a forrása, hanem az, hogy valaki hozzáfér-e állami megrendeléshez, szubvencióhoz, járadékoz. A szellemi tőke helyét a kapcsolati töke foglalja el. Ennek következménye az instabil intézményrendszer és jogrendszer, hiszen az éppen erösebb csoport a saját igényei szerint módosítja a járadékszabályozókat - miközben a pillanatnyi hátrányban lévő, de korántsem gyenge ellentábor az új elóírások megvalósulását folyamatosan megakadályozza. A patrónus-kliens körhöz tartozók elég erősek ahhoz, hogy a klientúrába tartozó társaikat megvédjék cselekedeteik jogi következményétöl (és ezzel persze a teljes hálózatot, amely nyilvánvalóan érdekelt), így nincs vagy alig van valószínüsíthető negatív következménye a korrupt magatartásnak. Ez szinte törvényszerüvé teszi a korrupció elburjánzását a jelenlegi Magyarországon." (Sajó 2008 697.). A jelenség vizsgálatával foglalkozó hazai és nemzetközi szervezetek (Transparency Int. 2011) kivétel nélkül növekedést tapasztalnak ezen a területen, továbbá, hogy a korrupciót egyre inkább szervezett formában és egyre kevésbé alkalmi 
jelleggel követik el. Így semmiképpen nem megalapozatlan azt állitani, hogy ez jelentékeny résszel csökkenti a nemzet láthatatlan vagyonát.

\section{9. Üzleti élet nyitottsága}

Az üzleti élet nyitottságának minösítésekor azt kell elemezni, hogy a nemzetgazdaság szereplöi határon átnyúló ügyleteiket mennyire szabadon és egyszerüen tudják bonyolítani. Jellemzően a külkereskedelmet, a pénzügyi müveleteket, a közvetlen tőkeberuházásokat, a más nemzetek polgárai által végzett munkaszolgálatokat és az információáramlást kell minösíteni a szabadság és egyszerüség szemszögéböl. Hazánk talán ebben éri el a legjobb minösitést, hiszen fokozatosan egyre nagyobb teret ad a nemzetközi ügyletek, valamint a világ más részein élő és müködő magánszemélyek valamint vállalkozások kapcsolatainak a kiteljesedéséhez. Az üzleti élet szokásos nyitottsági mutatóinak értékei közül legrelevánsabb a globális komplex versenyképességi rangsorban elfoglalt helyezés. Ezek fontos jellemzöje, hogy több almutatóból állnak, lehetővé téve az egyes országok erősségeinek és gyengeségeinek feltérképezését. A másik fontos jellemzöjük, hogy a mutatók egy része statisztikai adat, míg a másik részét vállalatvezetők szubjektiv véleménye alapján állítják össze. Ezen komplex versenyképességi rangsor alapján hazánk 2010-ben az 52. helyen állt (World Economic Forum 2010). Ez és más mutatók értékei alapján megállapítható, hogy nemzetközi összehasonlításban is nagyon nyitottnak minösítik hazánkat, ez az intézményi elem tehát jelentősen emeli a nemzet láthatatlan vagyonát.

\subsection{MAGÁNBERUHÁZÁSOK}

A sort a magánberuházások helyzetének jellemzésével zárom. A beruházási döntésekben tulajdonképpen a gazdasági szereplök jövöbe vetett hite, várakozása nyilvánul meg. Hazánkban a válság, a negatív gazdasági kilátások és az alacsony a megtakarítások miatt 2007 óta folyamatosan csökken a nemzetgazdasági beruházások volumene (MKIK GVI 2011). Ebben az jut kifejezésre, hogy a potenciális beruházóknak negatív várakozásaik vannak, nem bíznak befektetésük megtérülésére, ezért elhalasztják beruházásaikat. Mivel a privatizációs folyamat is lezárult, véget ért, így már nincs mit értékesíteni (TWSJ 2011), ezért a külföldröl beáramló befektetésekből is egyre kevesebb fog érkezni, amit csak még inkább erősít a mai pénzügyi krízisből kibontakozódó gazdasági válság beruházási forrásokat csökkentő hatása. Véleményem szerint a hazai gazdaság túladóztatott állapota is a beruházási források továbbapadását eredményezi. Igy ezek együttes hatása, hogy a magánberuházások folyamatosan zsugorodnak. Ezt bizonyítja, hogy a közelmúlt éveiben a nemzetgazdasági beruházások még az amortizáció összegét sem pótolták (KSH 2011), igy megalapozott kijelenteni, hogy az ilyen szintü beruházások nem képesek hozzájárulni a gazdasági növekedéshez, amiből következik, hogy jelenleg nincs pozitív szerepük a nemzet láthatatlan vagyonában.

\section{KÖVETKEZTETÉSEK}

Megvizsgálva és elemezve Magyarország intézményrendszerének releváns elemeit az alábbi következtetéseket vonom le:

A vizsgálat alá vont, kiemelt jelentöségü intézményi elemek közül többeket közvetlenül, míg másokat közvetetten érintenek a gazdasági válság hatásai és a kormányzat megszorító intézkedései. Az elszámoltatósághoz, valamint az államigazgatás hatékonyságához hozzájáruló igazságszolgáltatás pénzügyi és humán forrásainak csökkentése azok intézményi értékét mérséklik, ily módon negatívan befolyásolják a társadalmi jólétet.

Elöző megállapításnál triviálisabb az, hogy a korrupció elleni küzdelem ráfordításait nem csökkenteni, ellenkezőleg növelni kell, mivel az egyéni haszonszerzés miatt történö, 
közhatalommal való visszaélés az egyik legdurvább módja a közjó lerombolásának, devalválásának.

A tanulmányban említett humán tỏkét, annak versenyképességét determináló köz- és felsỏoktatásból elvont, alapos hatástanulmányokkal alá nem támasztott forráselvonások direkt módon csökkentik az érintett intézményi elemek értékét, ebből következően egyre alacsonyabb hatásfokkal tudnak hozzájárulni a nemzeti vagyonhoz, annak növekedéséhez.

$\mathrm{Az}$ elemzés és értékelés végére érve bizonyosságot nyert az, hogy egy nemzet jólétének megítéléséhez, vagyonának értékeléséhez ma már nem elég csak és kizárólag a naturáliákban kifejezhető gazdasági jellemzőket figyelembe venni (amint azt korábban tették), a fent részletezett és minősített láthatatlan javak is meghatározóan járulnak hozzá annak nagyságához, azért mert ezek önmagukban is jelentős értéket képviselnek, egymást erösítve pedig döntővé válnak az értékteremtésben, ezzel a láthatatlan nemzeti vagyon növekedésében.

Mérlegre téve az elözöekben megfogalmazott minösítéseket, azt állítom, hogy hazánk láthatatlan intézményrendszeri vagyonelemei összességében magas értéket képviselnek, így jó alapot képeznek arra, hogy hosszabb távon a nemzet jóléte növekedjen. Ehhez azonban elengedhetetlen a pozitív szerepüek továbbfejlesztése, valamint a negatív minősítésű intézményi vagyonelemek fokozatos és folyamatos korrekciója, illetve - szükség szerint egyesek felszámolása.

\section{FELHASZNÁLT IRODALOM}

Alkotmánybíróság (1991): 3/1991.(Il.7.) sz. határozata. Budapest.

Báger G. - Pulay Gy. - Vigvári A. (2010): A magyar állammüködés főbb jellemzői és szükséges változásainak irányai. Pénzügyi Szemle. 55. évf. 2.

Bailey, R. (2007): The Secrets of Intangible Wealth. For once the World Bank says something smart about the real causes of prosperity. Reason Magazine. October 5.

$\mathrm{KSH}$, (2011): A nemzetgazdaság integrált számlái 2010, Budapest, 2011, http://www.ksh.hu/docs/hun/xstadat_xstadat-hosszu/int2010a.html,Letöltés ideje: 2012-05-05

MKIK Gazdaság- és Vállalkozáskutató Intézet (2011): Rövidtávú munkaerő-pici prognózis 2012, Budapest, 2011. november

Putnam, R. D. (1983): The Prosperous Community - Social Capital and Public Life. The American Prospect. Volume 4/13., pp. 27-40., Washington D.C.

Sajó András (2008): Az állam müködési zavarainak társadalmi újratermelése. Közgazdasági Szemle. 55. évf. 7- 8 .

The Wall Street Journal (2011): Privatization Has Ended in Hungary. Minister Says. http:blogs.wsj.com/emergingeurope/2010/05/13/privatization-has-ended-in-hungary-ministersays. Letöltés ideje: 2012-04-11

Török Ádám (2007): A versenyképesség egyes jogi és szabályozási feltételei Magyarországon. Közgazdasági Szemle. 54. évf. 12.

Transparency International (2011): The current Corruption Perceptions Index was launched 1 December, 2011., http://cpi.transparency.org/cpi2011/ Letöltés ideje: 2012-02-21

Utasi Ágnes (2009): A minőségi élet kapcsolatai. Országos Tudományos Kutatási Alapprogramok. www. otka.hu/index. php? akt_menu=4084. Letöltés ideje: 2012-02-16

World Bank (2006): Where is the wealth of nationos? Measuring Capital for the 21 st Century. Washington D.C.

http://siteresources.worldbank.org/INTEEI/2145781110886258964/20748034/All.pdf.

Letöltés ideje: 2012-01-21

World Economic Forum (2010): The Global Competitiveress Report 2010-2011. Geneva, Switzerland.http://www3.weforum.org/docs/WEF_GlobalCompetitivenessReport 201011.pdf Letöltés ideje: 2012-01-21 